\title{
Teacher Competence and Its Relation to the Development
}

\section{of Indonesian Language Teaching Materials}

\section{preliminary}

The demands of professional teachers are one of the competencies that teachers must possess. Professional competence of a teacher by having competencies, among others, can develop professionalism in a sustainable manner by taking reflective actions, and using ICT to communicate and develop themselves.(Shahrul Ramadhan, Sukma, Indriyani, Language, \& Padang, 2019). This means that scientific publication training for teachers is a professional development in the form of work as a reflective action for professional teachers. Professional teachers must be able to adapt to increasingly sophisticated technological developments(Novauli, 2015). This will test the existence of professional teachers with their ability to use digital-based media and learning resources(S. Ramadhan, Atmazaki, Sukma, \& Indriyani, 2021).

According to(Shahrul Ramadhan, Sukma, \& Indriyani, 2019), Education is the key to build a nation. Education creates talented people who are able to compete in the development of science and technology. The development of science and technology is to create conditions in which all countries can improve the quality of education. Teachers are an important factor in determining educational progress. Therefore, teacher qualifications need to be maintained and improved. Learning activities determine the quality of a teacher. The government sets curriculum policy standards with the aim of improving the quality of education, but teachers usually do so and determine whether the quality of learning affects the quality of education. 
Next according to(Domalewska, 2014), the use of ICT multimedia such as sound, animation, and pictures can engage students in learning and increase their knowledge and motivate them to learn better. The use of multimedia aims to make it easier for students to determine what and how they can absorb information quickly and efficiently(Mulyadi, Syahrul, Atmazaki, \& Agustina, 2020). The ability of multimedia technology that is getting better and developing will increase the ease of obtaining student knowledge.(Hamzah \& Muhlisrarini, 2014)said that the use of multimedia in learning plays an important role in the academic value of student learning. With multimedia, it is hoped that students will find it easier to determine what and how students can absorb information quickly and efficiently because learning resources are no longer focused on textbooks.

Language plays an important role in human life(Atmazaki, Ramadhan, Indriyani, \& Nabila, 2021). Language can develop intellectual, emotional, and spiritual intelligence(Tampubolon, 2018). The development of self-study modules for Indonesian language lessons is expected to be no longer teacher-centered, but rather a student-centered learning system(Shahrul Ramadhan, Indriyani, Asri, \& Sukma, 2020). Competencies of graduates who are able to develop visual communication concepts in digital media(Mursal, Ramadhan, Ermanto, \& Atmazaki, 2019). The focus of development in this study lies in the presentation of independent learning materials in which there is material management, display, and student control. So does teacher competence have anything to do with the development of Indonesian language teaching materials?

\section{Discussion}

Teachers in the learning process in the classroom are seen as being able to play an important role, especially in helping students to build positive attitudes in learning, arouse 
curiosity, encourage independence and accuracy of intellectual logic, and create conditions for success in learning. The performance and competence of teachers bear the main responsibility in the transformation of student orientation from ignorance to knowledge, from dependence to independence, from unskilled to skilled, with learning methods no longer preparing passive students, but knowledgeable students who are always able to absorb and adapt to new information by thinking, asking, exploring,(S. Ramadhan, Sukma, \& Indriyani, 2019).

Teacher competence is an educator's capacity and authority in completing Muhibbin's call for performances in education(Werdayanti, 2008). The ability of the instructor is very significant compared to student practice and learning outcomes. Learning interactions and student learning outcomes are not only determined by schools, examples, design, and content of educational programs, but are largely controlled by the ability of the instructors who educate and guide them. According to(Suryosubroto, 2002) teaching and learning measures include exercises carried out by instructors ranging from compiling, carrying out exercises to assessments and follow-up programs that occur in instructive circumstances to achieve certain goals, especially educating (S. Ramadhan et al., 2019).

Something that can be included in acceptable teaching is with the help of innovation in learning, namely the use of computerized demonstration materials, especially in Indonesian language learning that can utilize hardware, in the form of books, modules, student worksheets, etc.(Yasuda, Zhang, Yamamoto, \& Sumita, 2008). Showing material is one of the important segments in language learning(Meli, 2015). Completing the material presented will help strengthen the substance and interest of students by providing different explanations and practices and expand the material by adding various components that are valuable for students (Islam and Mares, 2003) in(Tabari, 2013). Showing material will significantly affect the nature of learning in the classroom because showing material is a powerful method for reflecting learning(Richards \& Renandya, 2002). Showing material is planned depending on the security 
and progress of teaching, so the material show can be a hotspot for intervention and work with educating and learning(Tomlinson, 2007).

\section{Closing}

Teachers play an important role in achieving learning objectives, because educators can determine the number and nature of the performances they perform. To obtain quality learning, one's ability is needed. Teachers as educators are sources of information needed by students, instructors must have this information, by having great information and abilities, it is clear that instructors will really want to solve problems in the classroom.

The teacher connotes the extent to which a person performs activities both related to duties and obligations in accordance with the level of competence he masters or in other words performance as behavior is more driven and coordinated by a number of knowledge and information that is controlled by a person in carrying out activities according to the demands of his duties. Teacher performance can be expressed as the level of success of a teacher as a whole in a certain period of time which can be measured based on three indicators, namely: mastery of teaching materials, ability to manage learning, and commitment to carrying out tasks.

\section{BIBLIOGRAPHY}

Atmazaki, Ramadhan, S., Indriyani, V., \& Nabila, J. (2021). Dialogic-Interactive Media Design for Language Learning to Improve Speaking Activities and Skills. Journal of Physics: Conference Series, 1779. 
Domalewska, D. (2014). Technology-supported classroom for collaborative learning: Blogging in the foreign language classroom. International Journal of Education and Development Using Information and Communication Technology (IJEDICT), 10(4).

Hamzah, A., \& Muhlisrarini. (2014). Mathematics Learning Planning and Strategy. Jakarta: Rajagrafindo Persada.

Meli. (2015). Evaluation of the Preparation of Phonetics Teaching Materials on Chinese Language Teaching Materials. Journal of Language \& Literature, 15(2).

Mulyadi, Syahrul, R., Atmazaki, \& Agustina. (2020). The Development of E-Modules Based on Adobe Flash for Indonesian Subjects at IAIN Bukittinggi. Journal of Physics: Conference Series, 1471.

Mursal, Ramadhan, S., Ermanto, \& Atmazaki. (2019). The Development of A Fairy Tale Text Learning Model Using Problem Based Learning Approach in Class IV Elementary School. Proceedings of the Eighth International Conference on Languages and Arts, 463.

Novauli, MF (2015). Teacher Competence in Improving Learning Achievement at State Junior High Schools in Banda Aceh City. Journal of Educational Administration: Unsyiah Postgraduate Program, 3(1).

Ramadhan, S., Atmazaki, Sukma, E., \& Indriyani, V. (2021). Design of task-based digital language teaching materials with environmental education contents for middle school students. Journal of Physics: Conference Series PAPER, 1811.

Ramadhan, S., Sukma, E., \& Indriyani, V. (2019). Teacher competence in utilizing digital media literacy in education. Journal of Physics: Conference Series, 1339.

Ramadhan, Syahrul, Indriyani, V., Asri, Y., \& Sukma, E. (2020). Design of Learning Modules 
Writing Narrative Text Based on Project Based Learning (PjBL) by Using Mobile Devices. Journal of Physics: Conference Series, 1471(1).

Ramadhan, Syahrul, Sukma, E., \& Indriyani, V. (2019). Environmental education and disaster mitigation through language learning. Earth and Environmental Sciences.

Ramadhan, Syahrul, Sukma, E., Indriyani, V., Language, F., \& Padang, UN (2019). Indonesian Language With Mobile Devices. XIII Language Examination International Seminar.

Richards, JC, \& Renandya, WA (2002). Methodoly in Language Teaching: An Anthology of Current Practice. Cambridge: Cambridge University.

Suryosubroto. (2002). Teaching and Learning Process in Schools. Jakarta: PT Rineka Cipta.

Tabari, AG (2013). Challenges of Language Syllabus Design in EFL/ESL Contexts. Journal of Language Teaching and Research, 4(4).

Tampubolon, DP (2018). Language and intelligence in communication. Scientific Journal of Communication Studies, 1(1).

Tomlinson, M. (2007). Graduate employability and student attitudes and orientations to the labor market. Journal of Education and Work, 20(4).

Werdayanti, A. (2008). The Influence of Teacher Competence in the Teaching and Learning Process in the Classroom and Teacher Facilities on Students' Learning Motivation. Educational Dynamics, 3(1).

Yasuda, K., Zhang, R., Yamamoto, H., \& Sumita, E. (2008). Method of Selecting Training Data to Build a Compact and Efficient Translation Model. Proceedings of the International Joint Conference on Natural Language Processing (IJCNLP). Hyderabad. 